\title{
What Is Collaboration? An Analytical Cut from the Business Processes and SaaS Perspectives
}

\author{
Maiara Heil Cancian ${ }^{1}$, Ricardo J. Rabelo ${ }^{1}$, and Christiane Gresse von Wangenheim ${ }^{2}$ \\ ${ }^{1}$ Department of Automation and Systems, \\ Federal University of Santa Catarina, Florianópolis, (SC) Brazil \\ ${ }^{2}$ Department of Informatics and Statistics, \\ Federal University of Santa Catarina, Florianópolis, (SC) Brazil \\ \{maiara, rabelo\} @das.ufsc.br, \\ gresse@inf.ufsc.br
}

\begin{abstract}
This paper refers to how the collaboration among members of a Virtual Organization composed of software services providers can be enlarged within a SOA/SaaS scenario, maintaining partners' independence, autonomy and heterogeneity. It considers the situation where software companies work collaboratively to meet business opportunities so attending wider markets in a more agile way and with less risk, taking advantage of opportunities, capacities and capabilities that they would not have alone. Working collaboratively is not a mere wish. Companies should know and be prepared for supporting the required processes and to implement related practices. That is the goal of this article and ongoing research: to elicit the additional processes that are necessary to be supported by such a companies in the act of collaborating under the SOA/SaaS scenario.
\end{abstract}

Keywords: Collaboration, Business Process, Software Providers, SaaS.

\section{Introduction}

An increasing number of organizations have been investing in strategic alliances focused on larger collaboration as an alternative to increase competitiveness through innovation and productivity [1]. Collaborative Networks (CN) allow companies to keep focused on their skills and to aggregate competencies with other companies in order to offer products with higher value to meet businesses [2].

Despite turbulences in the global economy, the result was reasonably stable for the ICT (Information and Communication Technology) industry [3]. Part of this favorable scene is due to the expansion of cloud computing concept, putting these companies ahead of the technological innovations available, as the movement related to outsourcing and virtualization software [4].

Following the Cloud Computing, web applications can be developed using some approaches, like SOA (Service-Oriented Architecture). SOA provides flexibility in systems project and facilitates their integration, allowing the creation of interoperable services that can more easily be reused and shared across applications [5]. This 
scenario creates new needs and challenges. On the side of business users, they are increasingly pressured to streamline and better improve the growing investment in ICT [6]. On the side of developers, they are also pressured to provide services that can add value to companies to stay in the market. In this context, the business, architectural and availability model "Software-as-a-Service" (SaaS), combined with SOA, is ascending more and more in significance [7].

Generally, SaaS is a form of software which is available on demand via Internet and that is paid for use. In this model companies stop buying licenses and start renting specific software services. Developing their software solutions as services/SaaS puts companies ahead of the issues of innovation, bringing benefits to customers and suppliers [8]. This happens because the technologies used in this model are emerging and have the potential to leverage new sustainable models as they are loosely coupled and can be accessed from the cloud [9].

The essential issue tackled in this paper and underlying research question refer to how the collaboration among $\mathrm{CN}$ members within that SOA/SaaS scenario can be enlarged, maintaining partners independence, autonomy and heterogeneity. More precisely, it considers the situation where $\mathrm{CN}$ members are software companies that want / need to work collaboratively to meet business opportunities so attending wider markets in a more agile way and with less risk, taking advantage of opportunities, capacities and capabilities that they would not have alone [10]. In this scenario, services providers try to join their individual services into a composite and more valuable (SOA/SaaS-based) solution to be offered to the market, being it on demand or prospectively. To this model the authors of this paper have been calling as "Collaborative SaaS", seeing the so-called independent software vendors (ISV) as independent service providers (ISP).

Collaboration between software development companies in the SaaS model is a quite new concept and involves a number of challenges and issues. In this research, it is of interest to face two of them: i) how to select the most adequate ISP, i.e. how to trust on the others' services quality and reputation to minimize technical problems in that global solution ? ii) which actions are effectively involved in a collaboration among a CN of ISP ?

For the first question authors have already developed a reference guide for software quality devoted to SOA/SaaS, which was based on reference models for software quality improvement [11]. The second question refers to what this paper is about: which business processes are involved in such collaborative scenario?

It is important to understand what collaboration indeed means in this context as working collaboratively is not a mere wish. Companies should know and be prepared for supporting the required processes and to implement related practices. That is the goal of this article and ongoing research: to contribute to understand and to elicit the additional processes that are necessary to be supported by ISPs in the act of collaborating under the SOA/SaaS scenario.

This article is organized as follows: section 2 presents a general description of the main forms of collaboration in the context of this research. Section 3 presents a literature review, and section 4 presents the conclusions of this article. 


\section{Collaboration Forms}

Collaborative-SaaS grounds on $\mathrm{CN}$, which represents the more general theoretical foundation that characterizes the diverse manifestations of collaboration between organizations. This involves the structure, behavior and evolution dynamics of networks of autonomous entities that collaborate to better achieve common or compatible goals [12].

Regarding the envisaged collaboration between ISP, the $\mathrm{CN}$ manifestation called Virtual Organization (VO) represents quite well the scenario. A VO corresponds to a temporary and dynamic strategic alliance of autonomous, heterogeneous and usually geographically dispersed companies or professional communities that are created to attend to particular business opportunities, sharing costs, benefits and risks, acting as one single enterprise. After ending all legal obligations a VO is dismissed [13]. Under this view, a VO should be created, operated and managed regarding its intrinsic dynamics, and ended [6].

In the Creation phase the business is identified, the most suitable ISPs are selected for its parts (based on a variable set of criteria, including the quality of their software development processes), the governance model is instantiated, related performance indicators and metrics are settled, the software development project as a whole is designed and set up, SLAs are specified and contracts signed, and the VO is launched. In the Operation phase the whole development project is constantly monitored to ensure the collaboration is on the track, that the involved processes are being correctly performed and that performance metrics and SLAs are being fulfilled. In the Evolution phase, some actions should be planned to handle problems that happen in the Operation phase. Examples of problems include the inability of a partner to execute its task in time, the need to increase the workload, some metrics are well below to the agreed plan, etc. These problems usually lead to the addition, withdrawn or replacement of a partner (which should be selected again); to changes in specifications, contracts, agreements, etc.; or even to the business cancellation in a very serious case. The Dissolution phase embraces business processes involved with all technical, organizational, financial, legal and regulatory aspects related to the VO ending. This can happen either when business has been properly accomplished (i.e. VO / ISP partners delivered the services solution as contracted) or when the VO did not succeed due to major problems.

Therefore, acting collaboratively under the SaaS model to attend to business opportunities demands many other processes from the VO members than just putting pre-selected and a priori known companies to write services' code separately and to integrate and bundle them afterwards.

\section{$3 \quad$ Literature Review}

\subsection{Methodology}

Regarding the essentially exploratory characteristic of this research, the literature review procedure was considered as the most suitable for the case. Yet, considering 
the relatively novelty of the envisaged scenario and Collaborative-SaaS, there is not much real case scenarios upon which a rigorous analysis can be based on. Thus, and for a preliminary elicitation of the business processes involved in that form of collaboration, the revision was based on the state-of-the-art.

In order to gather a comprehensive revision of the state-of-the-art, the method SLR (Literature Systematic Review) [14] was chosen. SLR corresponds to a way to identify, evaluate and interpret all available research relevant to a specific research question, topic area or phenomenon of interest. It involves different activities and stages along three main phases: Planning, Conduct and Report.

In short, Planning phase frames the research objectives and defines the so-called protocol review. It describes the essential research question - what are the processes involved in collaboration? - and how the review itself will be conducted. This was done via defining a set of keywords and acronyms which can cover that question as well as exclusion criteria. The respective search string was then drawn up. Articles written in English and published in journals and in conference proceedings between Sept 2000 and Sept 2011 have defined the search scope. As sources of information it was mainly considered the most recognized scientific repositories in the related area: IEEExplore, ACM Digital Library, Compendex/Engineering Village, and ScienceDirect.

In the Conduct phase the primary results from that search should be identified, evaluated and selected. The metadata (title, keywords and abstract) has to be extracted and synthesized for each retrieved/selected paper. In this work, the search returned a total of 278 articles. These articles were read and their contents were evaluated to see at which level of depth they indeed dealt with collaborative processes among enterprises. Actually it was observed that a large amount of those papers covered collaboration (in the paper's context) at a very shallow level, sometimes just pointing out the need for such processes. After a more rigorous analysis nine papers were taken as the main theoretical referential for this research: [6, 15, 16] [17-22].

The last phase, Report, aims at consolidating the results out of this referential. These activities were used to check aspects like redundancies (i.e. different processes' definitions dealing with equivalent concepts), synonyms (i.e. different words but with the same meaning) and semantics misleading (i.e. definitions of processes that were in fact more related to other process' definition), so to have a more precise and compiled list of collaborative processes.

\subsection{Preliminary Results}

With the processes compiled with 'standardized' names and descriptions, they were categorized according to the proper VO life cycle. This categorization also aimed to facilitate the processes organization as well as their visualization. Due to a more variety, the processes within Operation and Evolution phases were organized into subcategories, regarding their intrinsic nature and also weighing up what the authors of those referential papers stated about. Besides a comparison among such papers, a number of supporting books were taken into account for that 'standardization', [23] in particular. 
Table 1 presents the elicitation of the business processes required to support the collaboration among ISP in a SOA/SaaS scenario from a VO point of view. It is important to mention that this list complements the other traditional processes of software development solidly covered by some reference models, like CMMI [24]. In other words, it means that this new scenario requires additional processes - which can be called collaborative business processes - besides the traditional ones, like project management, risk management, configuration management, verification and validation.

It is also important to mention that this list does not represent the processes that any 'traditional' SaaS provider should follow, but rather which processes should be taken into account when an ISP wants to collaborate with others.

Table 1. Processes for Collaborative SaaS

\begin{tabular}{|c|c|c|}
\hline PHASE & PROCESSES & DESCRIPTIONS \\
\hline \multirow{7}{*}{ 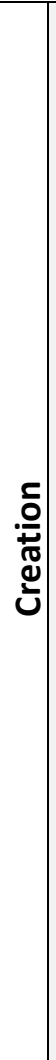 } & $\begin{array}{l}\text { Business Opportunity } \\
\text { characterization }\end{array}$ & $\begin{array}{l}\text { Involves the identification and characterization of a new } \\
\text { collaboration opportunity that will trigger the formation of } \\
\text { a new SaaS collaboration. }\end{array}$ \\
\hline & $\begin{array}{l}\text { Selection of } \\
\text { performance } \\
\text { indicators }\end{array}$ & $\begin{array}{l}\text { To use the monitoring data to the partner selection. The } \\
\text { performance indicators to be used in the monitoring must } \\
\text { to be defined by the SaaS collaboration group. }\end{array}$ \\
\hline & Partner Search & $\begin{array}{l}\text { Identification of potential partners, and their assessment } \\
\text { and selection to be a SaaS provider. }\end{array}$ \\
\hline & Partner Selection & $\begin{array}{l}\text { To select a SaaS partner are considered elements like } \\
\text { technical, reliability indicators, preferences, consideration } \\
\text { of collaboration history, external search and indicators } \\
\text { based on past performance of enterprise members. }\end{array}$ \\
\hline & $\begin{array}{l}\text { Negotiation \& Risk } \\
\text { Analysis }\end{array}$ & $\begin{array}{l}\text { Set of management activities and supporting tools that will } \\
\text { assist human actors (partners) during the negotiation } \\
\text { processes and risk analysis assessment towards the SaaS } \\
\text { collaboration constitution. }\end{array}$ \\
\hline & E-Contracting & $\begin{array}{l}\text { Involves the final formulation and modeling of contracts } \\
\text { and agreements as well as the contract signing process } \\
\text { itself, before the SaaS collaboration can effectively be } \\
\text { launched. }\end{array}$ \\
\hline & Collaboration Planning & $\begin{array}{l}\text { Determination of a rough structure of the potential SaaS } \\
\text { collaboration, identifying the required competencies and } \\
\text { capacities, structure of the task to be performed as well as } \\
\text { the organizational form of the SaaS collaboration and } \\
\text { corresponding roles. }\end{array}$ \\
\hline
\end{tabular}


Table 1. (continued)

\begin{tabular}{|c|c|c|c|}
\hline \multirow{5}{*}{ 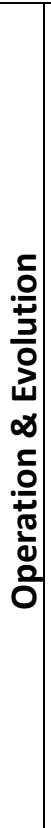 } & \multirow{5}{*}{ 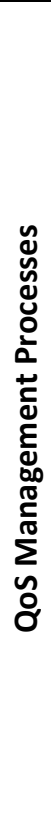 } & Trust Management & $\begin{array}{l}\text { To promote the establishment of trust relationships among } \\
\text { SaaS participants, including the assessment of the trust } \\
\text { level among members. }\end{array}$ \\
\hline & & $\begin{array}{l}\text { Governance } \\
\text { Management }\end{array}$ & $\begin{array}{l}\text { Set of management activities and supporting tools that } \\
\text { refer to the SaaS collaboration policy management, } \\
\text { including internal operational rules and bylaws, for } \\
\text { supporting the operation, regulation, and control of the } \\
\text { network structure. }\end{array}$ \\
\hline & & $\begin{array}{l}\text { Measurement and } \\
\text { analysis }\end{array}$ & $\begin{array}{l}\text { To develop and sustain a measurement and analysis } \\
\text { capability of the SaaS collaboration that is used to support } \\
\text { management information needs. }\end{array}$ \\
\hline & & $\begin{array}{l}\text { Decision Support } \\
\text { Management }\end{array}$ & $\begin{array}{l}\text { Set of management activities and supporting tools for } \\
\text { decision support, using monitoring key performance } \\
\text { indicators in the SaaS collaboration. }\end{array}$ \\
\hline & & $\begin{array}{l}\text { Process and Product } \\
\text { Assurance }\end{array}$ & $\begin{array}{l}\text { Provides appropriate conformance guidance and } \\
\text { objectively reviews the activities and SaaS work products } \\
\text { of work efforts within the collaboration to ensure they } \\
\text { comply with applicable laws, regulations, standards, } \\
\text { organizational policies, business rules, process } \\
\text { descriptions, and work procedures. }\end{array}$ \\
\hline \multirow{6}{*}{$\begin{array}{l}\frac{c}{0} \\
\frac{0}{2} \\
\frac{2}{0} \\
\frac{3}{\infty} \\
\infty \\
\frac{c}{0} \\
\frac{0}{0} \\
\frac{0}{0} \\
0 \\
0\end{array}$} & \multirow{6}{*}{ 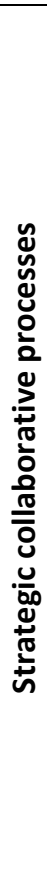 } & Strategic Management & $\begin{array}{l}\text { Is formulating, implementing and evaluating functional } \\
\text { decisions that will enable a SaaS collaboration to achieve } \\
\text { its objectives, including supportive strategic programs to } \\
\text { ensure the evolution of the collaboration. }\end{array}$ \\
\hline & & $\begin{array}{l}\text { Collaborative } \\
\text { Customer Relationship } \\
\text { Management }\end{array}$ & $\begin{array}{l}\text { To manage the interaction of potential or actual SaaS } \\
\text { customers with the collaboration, using enterprises data } \\
\text { and information. }\end{array}$ \\
\hline & & $\begin{array}{l}\text { Organizational } \\
\text { Innovation }\end{array}$ & $\begin{array}{l}\text { To select and deploy incremental and innovative } \\
\text { improvements that measurably improve the SaaS } \\
\text { collaboration's processes and technologies }\end{array}$ \\
\hline & & Collaborative Strategy & $\begin{array}{l}\text { Investment in core strategies to improve the SaaS } \\
\text { collaboration, develop provider competence and improve } \\
\text { the general network. }\end{array}$ \\
\hline & & $\begin{array}{l}\text { Reconciling Individual } \\
\text { and Collective } \\
\text { Interests }\end{array}$ & $\begin{array}{l}\text { Achieving individual organizational missions and } \\
\text { maintaining an identity that is distinct from the } \\
\text { collaborative and a collective interest. Achieving } \\
\text { collaboration goals and maintaining accountability to } \\
\text { collaborative partners. }\end{array}$ \\
\hline & & Simulation & $\begin{array}{l}\text { A simulation component should be available to generate } \\
\text { scenarios reflecting the effects of the implementation of } \\
\text { strategic decisions, evolving SaaS and collaboration. }\end{array}$ \\
\hline
\end{tabular}


Table 1. (continued)

\begin{tabular}{|c|c|c|c|}
\hline \multirow{8}{*}{ 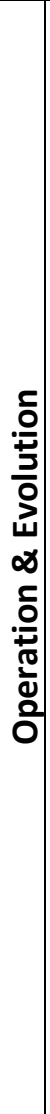 } & \multirow{8}{*}{ 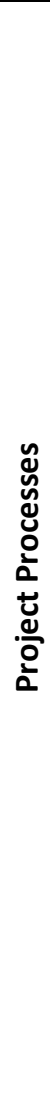 } & $\begin{array}{l}\text { Collaborative Project } \\
\text { Management }\end{array}$ & $\begin{array}{l}\text { To establish and manage the project Collaborative SaaS } \\
\text { and the involvement of the relevant stakeholders. }\end{array}$ \\
\hline & & $\begin{array}{l}\text { Requirements } \\
\text { Management }\end{array}$ & $\begin{array}{l}\text { To manage the requirements of the SaaS project's } \\
\text { products and product components and to identify } \\
\text { inconsistencies between those requirements and the } \\
\text { project's plans and work products. }\end{array}$ \\
\hline & & $\begin{array}{l}\text { Requirements } \\
\text { Development }\end{array}$ & $\begin{array}{l}\text { To produce and analyze customer, product and product } \\
\text { component requirements. }\end{array}$ \\
\hline & & Risk Management & $\begin{array}{l}\text { To identify potential problems before they occur so that } \\
\text { risk-handling activities can be planned and invoked as } \\
\text { needed across the life of the collaboration, product or } \\
\text { project to mitigate adverse impacts on achieving } \\
\text { objectives. }\end{array}$ \\
\hline & & $\begin{array}{l}\text { Quantitative Project } \\
\text { Management }\end{array}$ & $\begin{array}{l}\text { To quantitatively manage the project's defined process to } \\
\text { achieve the project's established quality and process- } \\
\text { performance objectives. }\end{array}$ \\
\hline & & $\begin{array}{l}\text { Partnership formation } \\
\text { project }\end{array}$ & $\begin{array}{l}\text { Negotiation of roles and responsibilities, deliverables and } \\
\text { payments related with SaaS collaborative project }\end{array}$ \\
\hline & & $\begin{array}{l}\text { Resources } \\
\text { Management }\end{array}$ & $\begin{array}{l}\text { Plans and manages the acquisition, allocation, and } \\
\text { reassignment of people and other resources needed to } \\
\text { prepare, deploy, operate, and support the collaboration } \\
\text { products and services. }\end{array}$ \\
\hline & & $\begin{array}{l}\text { Product Development } \\
\text { Collaboration }\end{array}$ & Software product development phases. \\
\hline \multirow{5}{*}{$\begin{array}{l}\frac{c}{0} \\
\frac{0}{3} \\
\frac{2}{0} \\
\frac{3}{\infty} \\
\infty \\
\frac{c}{2} \\
\frac{0}{0} \\
\frac{0}{0} \\
0\end{array}$} & \multirow{5}{*}{ 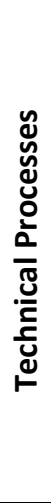 } & $\begin{array}{l}\text { Interoperability and } \\
\text { Collaboration } \\
\text { Technologies }\end{array}$ & $\begin{array}{l}\text { To standardize the usage of a set of baseline tools, } \\
\text { techniques and methods for interoperability and } \\
\text { collaboration. }\end{array}$ \\
\hline & & Technical Solutions & $\begin{array}{l}\text { To design, develop, and implement solutions to the } \\
\text { committed requirements between SaaS and collaboration. }\end{array}$ \\
\hline & & $\begin{array}{l}\text { System design and } \\
\text { task partitioning }\end{array}$ & $\begin{array}{l}\text { Modularity, interface definition and task } \\
\text { interdependencies in a SaaS development. }\end{array}$ \\
\hline & & $\begin{array}{l}\text { Support Institutions } \\
\text { Management }\end{array}$ & $\begin{array}{l}\text { Set of management activities and supporting tools for } \\
\text { identifying and integrating Support Institutions into the } \\
\text { SaaS collaboration. }\end{array}$ \\
\hline & & $\begin{array}{l}\text { Performance } \\
\text { Management }\end{array}$ & $\begin{array}{l}\text { Set of management activities and supporting tools based- } \\
\text { on a systematic procedure of planning, monitoring, rating } \\
\text { and rewarding collaboration actors' performance based-on } \\
\text { the definition of key performance indicators. }\end{array}$ \\
\hline
\end{tabular}


Table 1. (continued)

\begin{tabular}{|c|c|c|c|}
\hline & & ICT Management & $\begin{array}{l}\text { Set of management activities and supporting tools for } \\
\text { managing a low cost, easy-to-access and operational ICT- } \\
\text { infrastructure that will allow collaboration actors with } \\
\text { different distributed/heterogeneous applications to } \\
\text { communicate with each other transparently and } \\
\text { seamlessly, in order to support collaboration (businesses) } \\
\text { between them over the Internet. }\end{array}$ \\
\hline \multirow{7}{*}{$\begin{array}{l}\frac{c}{0} \\
\frac{0}{3} \\
\frac{2}{0} \\
\frac{1}{\infty} \\
\infty \\
\frac{c}{0} \\
\frac{0}{\pi} \\
\frac{0}{0} \\
0\end{array}$} & \multirow{7}{*}{ 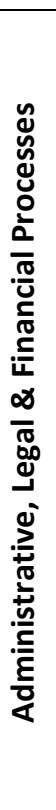 } & $\begin{array}{l}\text { Collaboration } \\
\text { Launching }\end{array}$ & $\begin{array}{l}\text { To refine the SaaS collaboration plan and its governance } \\
\text { principles, to formulate and model contracts and } \\
\text { agreements and to put the collaboration into operation. }\end{array}$ \\
\hline & & $\begin{array}{l}\text { Collaboration } \\
\text { Agreement }\end{array}$ & $\begin{array}{l}\text { To set up the terms in which the collaboration within the } \\
\text { enterprise takes place as well as the management of } \\
\text { throughout the whole life of a collaboration. }\end{array}$ \\
\hline & & $\begin{array}{l}\text { Marketing } \\
\text { Management }\end{array}$ & $\begin{array}{l}\text { Set of management activities and supporting tools that will } \\
\text { support the strategic formulation process, including the } \\
\text { marketing and branding activities, for promoting the } \\
\text { enterprise competencies among its potential SaaS } \\
\text { members and potential SaaS customers. }\end{array}$ \\
\hline & & Financial Management & $\begin{array}{l}\text { It is about planning income and expenditure, and making } \\
\text { decisions that will enable the enterprises survive } \\
\text { financially. }\end{array}$ \\
\hline & & $\begin{array}{l}\text { Accounting } \\
\text { Management }\end{array}$ & $\begin{array}{l}\text { Set of management activities and supporting tools based- } \\
\text { on accounting procedures to guarantee the enterprise } \\
\text { financial health and ensure the effective, efficient and } \\
\text { equitable use of the resources. }\end{array}$ \\
\hline & & $\begin{array}{l}\text { Value system } \\
\text { Information } \\
\text { Management }\end{array}$ & $\begin{array}{l}\text { Set of management activities and supporting tools that will } \\
\text { provide features for supporting and handling both, } \\
\text { material and immaterial values, within the collaboration. }\end{array}$ \\
\hline & & IPR Management & $\begin{array}{l}\text { (Intellectual Property Rights) to clarify and agree the terms } \\
\text { of the Intellectual Property Rights within the collaboration. }\end{array}$ \\
\hline \multirow{5}{*}{ 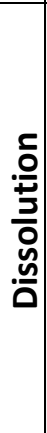 } & & $\begin{array}{l}\text { Collaboration } \\
\text { inheritance }\end{array}$ & $\begin{array}{l}\text { This task comprises the management of inheritance } \\
\text { information after collaboration dissolution. }\end{array}$ \\
\hline & & Partners assessment & $\begin{array}{l}\text { Is the final collaboration partners' assessment results. } \\
\text { Sharing the analysis results is dependent on the network } \\
\text { and the collaboration rules and practices. }\end{array}$ \\
\hline & & Checking contract & Finalization the collaboration contract terms. \\
\hline & & $\begin{array}{l}\text { Security access } \\
\text { cancellation }\end{array}$ & $\begin{array}{l}\text { Finalization the access between the enterprises } \\
\text { collaboration. }\end{array}$ \\
\hline & & Legal issues & $\begin{array}{l}\text { To finish the legal issues on the use of virtual companies } \\
\text { (with Collaborative SaaS), since they imply cooperation } \\
\text { agreements and might restrain concurrence between } \\
\text { partners and or between these and third parties. }\end{array}$ \\
\hline
\end{tabular}

\section{Conclusions}

This paper has described the results of an ongoing work, presenting a systematic literature review (SLR) on collaborative processes. Its essential goal was to provide a preliminary but comprehensive single and categorized list of processes to companies that are interested to collaborate to provide a more aggregated services solution within 
a SOA/SaaS scenario. On the other hand, and at this point of this research, it does not represent a list of "new" processes. Instead, it collects and provides some formalization of results from other isolated initiatives that somehow have tacked some forms of collaboration among companies.

This SLR about collaborative processes is part of a wider research, which aims at devising at the end, on top of existing software processes improvement reference models, one model devoted to and that can guide SaaS providers to work collaboratively.

Considering the essentially exploratory characteristic of this research and hence the relatively novelty of the envisaged collaborative scenario tackled in this paper, the SLR could only be carried out over state-of-the-art works. Very few initiatives with some equivalence with the so-called "collaborative SaaS" concept were found out in practice. In these cases, it could be observed that companies do that in an ad-hoc way, very much based on trust and on knowledge or relationships with previously known companies. Yet, they apply the same project management practices indicated in the classical reference models, and nothing grounded on a more solid foundation that considers SaaS in a more ample mode.

The collaborative processes that were elicited through this research should be taken as a complementary list of processes related to the other ones presented in reference models like CMMI and ISO15504. This means that such processes are additional actions that should be considered when SaaS providers want to work collaboratively to offer more valuable SOA/SaaS-based solutions instead of a mere group of individual / isolated services that should be further composed at the client side. This scenario leverages new and sustainable business models for SMEs of SOA/SaaS software providers.

Working collaboratively is not just a wish. Instead, it is a long process, of diverse natures and levels of impact. Thus, one of the most important usages of this list is to give awareness to SaaS providers about the impact on their processes. Therefore, they should be prepared for that, which is not trivial at all as this represents even still more processes to be coped with besides the 'traditional' ones.

SaaS itself and Collaborative SaaS are new areas, and more solid supporting theoretical foundations are required. For instance, it could be also realized that the elicited processes have different levels of complexity and scope if they want to be introduced in the daily life of those companies, which may even lead to think about adapting existing maturity models for that.

The provided list of processes related to collaboration has been verified only via a bibliography analysis. As such, next main short-term step refers to a validation of this close to a community of specialists (via the Expert Panel methodological technique). Yet, adequate practices to be associated to each process are currently being researched in order to provide a more concrete guidance to adopt the processes. ISO capability and SOA models will be used as a basis for. 


\section{References}

1. Gulati, R., Nohria, N., Zaheer, A.: Strategic Networks. In: Hahn, D., Taylor, B. (eds.) Strategische Unternehmungsplanung - Strategische Unternehmungsführung, pp. 293-309. Springer, Heidelberg (2006)

2. Camarinha-Matos, L.M., Afsarmanesh, H., Ollus, M.: Virtual Organizations - Systems and Practices, 340 pages. EUA, Springer (2005)

3. ABES, Brazilian Software Market - Overview and Trends 2010, Brazilian Association of Software Companies, p. 1-42 (2010) (in Portuguese)

4. Velte, A.T., Velte, T.J., Elsenpeter, R.: Cloud Computing - A pratical approach, 334 pages. The McGraw Hill, United States of America (2010)

5. Hongqi, L., Zhuang, W.: Research on Distributed Architecture Based on SOA. In: International Conference on Communication Software and Networks, ICCSN 2009, pp. 670-674 (2009)

6. Rabelo, R.: Advanced Collaborative Business Ict Infrastructures. In: Methods and Tools for Collaborative Networked Organizations, pp. 337-370. Springer (2008)

7. Zhiqiang, N.: Credibility evaluation of SaaS tenants. In: 2010 3rd International Conference on Advanced Computer Theory and Engineering (ICACTE), pp. V4-488-V4-491 (2010)

8. Laplante, P.A., Zhang, J., Voas, J.: What's in a Name? Distinguishing between SaaS and SOA. IT Professional 10(3), 46-50 (2008)

9. Junjie, P.: Comparison of Several Cloud Computing Platforms. In: Information Science and Engineering (ISISE), China, pp. 23-27 (2009)

10. Cancian, M.H., Hauck, J.C.R., von Wangenheim, C.G., Rabelo, R.J.: Discovering Software Process and Product Quality Criteria in Software as a Service. In: The 11th International Conf. Product Focused Software Develop. Ireland, pp. 95-103 (2010)

11. Cancian, M.H., Rabelo, R.J., von Wangenheim, C.G.: Supporting Software Services' Trustworthiness in Collaborative Networks. In: Camarinha-Matos, L.M., Boucher, X., Afsarmanesh, H. (eds.) PRO-VE 2010. IFIP AICT, vol. 336, pp. 672-684. Springer, Heidelberg (2010)

12. Camarinha-Matos, L., Afsarmanesh, H.: The Emerging Discipline of Collaborative Networks. In: Virtual Enterprises and Collaborative Networks. IFIP, vol. 149, pp. 3-16. Springer, Boston (2004)

13. Rabelo, R., Baldo, F., Tramontin, R., Pereira-Klen, A., Klen, E., Camarinha-Matos, L.: Smart Configuration of Dynamic Virtual Enterprises. In: Virtual Enterprises and Collaborative Networks, pp. 193-204. Springer, Boston (2004)

14. Kitchenham, B.: Guidelines for performing Systematic Literature Reviews in Software Engineering. EBSE Technical Report K, University, 87 pages (2007)

15. Alonso, J., Martínez de Soria, I., Orue-Echevarria, L., Vergara, M.: Enterprise Collaboration Maturity Model (ECMM): Preliminary Definition and Future Challenges. In: Enterprise Interoperability IV, pp. 429-438. Springer, London (2010)

16. Soria, I.M.d., Alonso, J., Orue-Echevarria, L., Vergara, M.: Developing an Enterprise Collaboration Maturity Model: Research Challenges and Future Directions. In: The 15th International Conference on Concurrent Enterprising 2009. The Netherlands, pp. 89-103 (2009)

17. Santanen, E., Kolfschoten, G., Golla, K.: The Collaboration Engineering Maturity Model. In: Proceedings of the 39th Annual Hawaii International Conference on System Sciences, vol. 01, pp. 16-26. IEEE Computer Society (2006) 
18. Fraser, P., Farrukh, C., Gregory, M.: Managing product development collaborations-a process maturity approach. Proceedings of the Institution of Mechanical Engineers Part B Journal of Engineering Manufacture, 1499-1519 (2003)

19. Fraser, P., Gregory, M.: A maturity grid approach to the assessment of product development collaborations. In: 9th International Product Development Management Conference, Sophia Antipolis, France, pp. 28-36 (2002)

20. Magdaleno, A.M., Araujo, R.M.d., Borges, M.R.S.: Designing Collaborative Processes. In: Business Process Management Workshops, pp. 156-168 (2007)

21. Thomson, A.M., Perry, J.L.: Collaboration Processes: Inside the Black Box. Public Administration Review 66, 20-32 (2006)

22. Romero, D., Galeano, N., Molina, A.: VO breeding environments value systems, business models and governance rules. In: Methods and Tools for Collaborative Networked Organizations, pp. 69-90. Springer (2008)

23. Camarinha-Matos, L., Afsarmanesh, H., Ollus, M.: Methods and Tools for Collaborative Networked Organizations, 532 pages. Springer Publishing Company, Incorporated (2008)

24. SEI, Software Engineering Institute (SEI) - CMMI for Development (CMMI-DEV). In Technical Report CMU/SEI-2006-TR-008, V. 1.2, Editor, Carnegie Mellon University / Software Engineering Institute, Pittsburgh, 198 pages (2006) 